\title{
The four of structural genes sequences of a porcine epidemic diarrhea virus from domestic piglet in Fujian, China
}

\author{
Bo Dong ${ }^{1,2^{*}}$, Ailing Dai ${ }^{1,2}$, Xiaohua $\mathrm{Li}^{1,2}$ and Xiaoyan Yang ${ }^{1,2^{*}}$
}

\begin{abstract}
A prevalent PEDV strain, designated FJLY06, was isolated from Fujian, China. The four of structural genes sequences of PEDV obtained were analyzed to determine their phylogenetic relationships and homology respectively, revealing that FJLY06 was highly homologous to virulent PEDV strains. The four structural genes all differed genetically from the vaccine strain CV777. The sequence alignment results further showed that $N, M$ and E genes of Chinese PEDV strains is highly conserved. Compared with the vaccine strain CV777, 8 mutations were detected in COE of FJLY06 S gene. The recombination analysis revealed FJLY06 is similar to other pandemic strains in China with a variant $S$ gene, and maybe a reason for recent vaccination failures.
\end{abstract}

Keywords: Porcine epidemic diarrhea virus, Spike gene, Small membrane gene, Membrane gene, Nucleocapsid gene, Phylogenetic analysis, Genetic characterization

\section{Introduction}

PEDV has four major structural proteins: spike (S), envelope $(E)$, membrane $(M)$, and nucleocapsid $(N)$ proteins [1]. Since the 1990s, a periodic vaccination strategy has been placed into effect on pig farms to control PEDV in China. However, these vaccines were not able to prevent the disease effectively in 2010. This suggests that the virulence of pandemic strains has become stronger, and might possibly provide protection to the CV777-based vaccine, thereby reducing the effectiveness of the vaccine. Analysis of a single structural gene may not really indicate genetic evolution because it reflects only a portion of the virus's genes, in contrast, using four structural genes may be eliminate the bias of using a single gene for genetic phylogenetic analysis in PEDV. A clear understanding of relevant epidemiological parameters is a key to planning better treatment and control strategies.

\footnotetext{
* Correspondence: 1906834157@qq.com; Lyyxy1988@126.com

${ }^{1}$ College of Life Science of Longyan University, Longyan 364012, China

Full list of author information is available at the end of the article
}

The sample was obtained from sucking piglets showing watery diarrhea and dehydration, which could not be cured with any commercial available antibiotic. The E, $\mathrm{M}, \mathrm{N}$ and $\mathrm{S}$ genes of this PEDV strain was cloned and sequenced to investigate the genetic characteristics and phylogeny of PEDV circulating in Fujian during this period. These data will provide a basis for further analysis of the genetic evolution of PEDV in China, and should help to develop a novel vaccine of PEDV for more effective prevention piglets from PEDV.

\section{Provenance of the virus material}

The FJLY06 was isolated from a sucking piglet collected in the Fujian province of China. After the piglet was necropsied, tissue samples of the intestinal, feces and intestinal contents from piglet were homogenized and 10\% $(\mathrm{w} / \mathrm{v})$ suspensions were made in sterile Dulbecco's phosphate-buffered saline (PBS, pH 7.2, 0.01 M). RNA was extracted from the sample using RNAiso Plus (TaKaRa, Tokyo, Japan). Reverse transcription was carried out and PCR was performed (Biometra, Germany)

\section{$\triangle B M C$}

(C) The Author(s). 2020 Open Access This article is licensed under a Creative Commons Attribution 4.0 International License, which permits use, sharing, adaptation, distribution and reproduction in any medium or format, as long as you give appropriate credit to the original author(s) and the source, provide a link to the Creative Commons licence, and indicate if changes were made. The images or other third party material in this article are included in the article's Creative Commons licence, unless indicated otherwise in a credit line to the material. If material is not included in the article's Creative Commons licence and your intended use is not permitted by statutory regulation or exceeds the permitted use, you will need to obtain permission directly from the copyright holder. To view a copy of this licence, visit http://creativecommons.org/licenses/by/4.0/ The Creative Commons Public Domain Dedication waiver (http://creativecommons.org/publicdomain/zero/1.0/) applies to the data made available in this article, unless otherwise stated in a credit line to the data. 


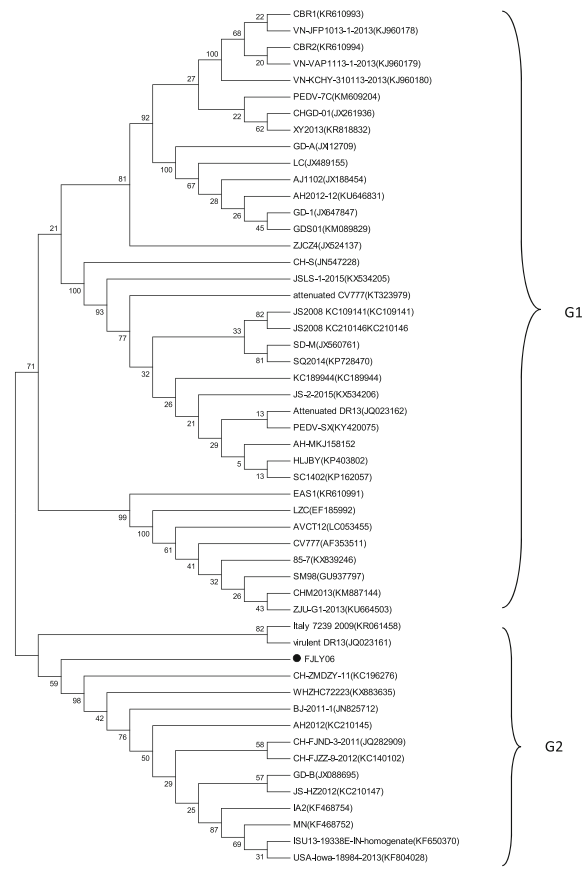

$\mathbf{a}$

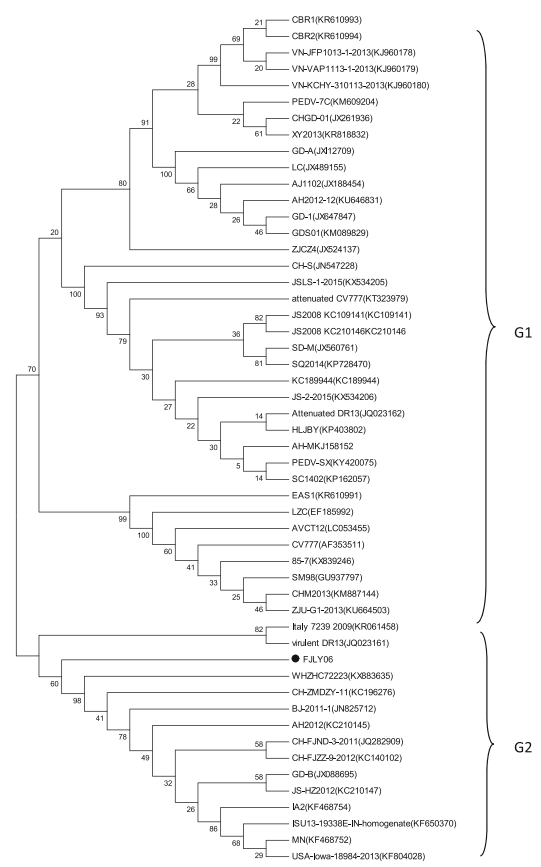

c

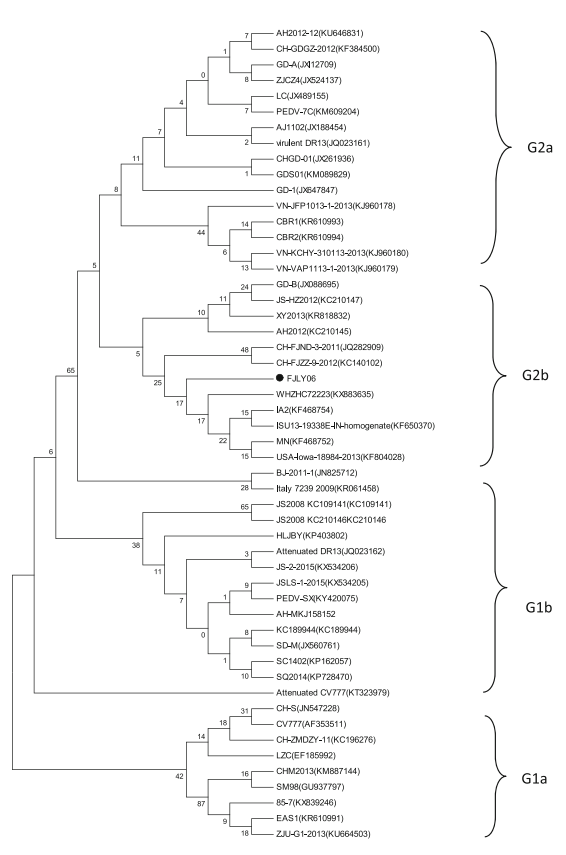

b

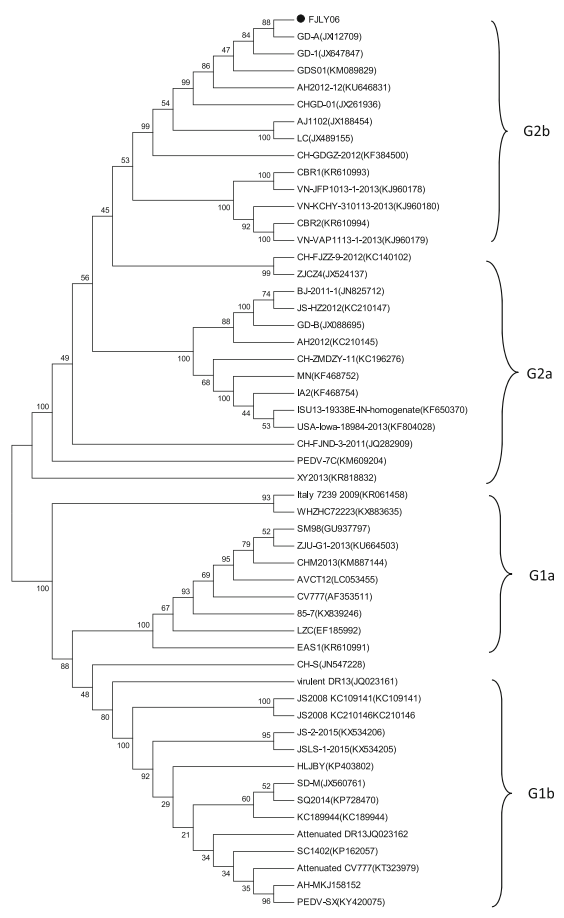

d

Fig. 1 Phylogenetic trees were constructed using MEGA 5.2 software based on comparisons of N, E, M and S nucleotide sequences. a Tree based on nucleotide sequences of $\mathrm{N}$ gene. $\mathbf{b}$ Tree based on nucleotide sequences of $\mathrm{E}$ gene. $\mathbf{c}$ Tree based on nucleotide sequences of $\mathrm{M}$ gene. $\mathbf{d}$ Tree based on nucleotide sequences of $\mathrm{S}$ gene

using the gene-specific primers. The amplified PCR products were subjected to gel electrophoresis, excised from the agarose gel, and purified using an Agarose Gel
DNA Purification Kit (TaKaRa). The clones were sent to Shanghai Sangon Biological Engineering Technology and Services Co., Ltd. (Shanghai, China) to be sequenced. 
The S, E, M and N gene sequences of the FJLY06 were edited, aligned and analyzed with the DNAMAN software. The nucleotides sequences were assembled into a multiple sequence alignment. Phylogenetic trees derived from the nucleotides sequences were constructed using the program MEGA version 5.2 [2]. The SimPlot 3.5 was used for similarity mapping and bootscanning analysis of potential reorganization events.

\section{Sequence properties}

Compared with the nucleotides sequences of 51 strains used in our study, the N gene of FJLY06 showed nucleotide identities of $94.3 \%$ to the vaccine strain CV777 used in China. Sequence comparison with the CV777 revealed that $\mathrm{E}$ gene of FJLY06 had nucleotide sequence identities of $96.5 \%$. The $\mathrm{M}$ gene had $98.7 \%$ identity to the CV777 vaccine strain. The nucleotide sequence homology results of S gene showed FJLY06 had the low DNA sequence identity to the CV777, which is $92.2 \%$.

The phylogenetic analysis found that the evolutionary relationship of N, M, E and S genes of the FJLY06 from our study were more closely with Chinese strains isolated after 2010, and belong to the PEDV strain variants. Meanwhile, the results showed that the FJLY06 from our study differed genetically from the vaccine strain (CV777) and other earlier PEDV strains found in China, South Korea and Belgium, as well as some classical strains (Fig. 1.)

Interesting, phylogenetic analysis showed that FJLY06 was located in the same subgroup with GD-01 collected previously from the Guangdong province of China [3], which is neighboring province of Fujian province, where FJLY06 is circulating. This result suggested whether animal transportation could be a risk factor in the spread of PEDV, because there was a relatively frequent flow of pigs or pork products between this two provinces in China.
Compared with the $\mathrm{N}$ gene of vaccine strain CV777, 12 mutations were detected in the amino acid sequence of the FJLY06 $(\mathrm{G} \rightarrow \mathrm{A}$ at $84, \mathrm{~K} \rightarrow \mathrm{N}$ at $123, \mathrm{~A} \rightarrow \mathrm{T}$ at $142, \mathrm{~N} \rightarrow \mathrm{K}$ at $204, \mathrm{R} \rightarrow \mathrm{K}$ at $241, \mathrm{H} \rightarrow \mathrm{L}$ at $242, \mathrm{~K} \rightarrow \mathrm{R}$ at $252, \mathrm{~N} \rightarrow \mathrm{S}$ at $255, \mathrm{~L} \rightarrow \mathrm{P}$ at $380, \mathrm{~L} \rightarrow \mathrm{Q}$ at $395, \mathrm{Q} \rightarrow$ $\mathrm{L}$ at 397 , and $\mathrm{E} \rightarrow \mathrm{D}$ at 400 ). There was no difference compared to those identified in Chinese strains isolated after 2010. In terms of amino acid sequence of $M$ genes, the G2 including the FJLY06 and other prevalent variant strains had the same three unique mutations as CV777, $(\mathrm{E} \rightarrow \mathrm{Q}$ at $12, \mathrm{~A} \rightarrow \mathrm{V}$ at 42 , and $\mathrm{A} \rightarrow \mathrm{S}$ at 213), and no difference was found in the M gene of the FJLY06 when compared to the other prevalent variant strains. It also had a unique point mutation in E gene of the FJLY06 compared with CV777 $(\mathrm{R} \rightarrow \mathrm{Q}$ at 65$)$, which was similar to the other strains of $\mathrm{G} 2$ group.

The S gene of PEDV contains four domains that can induce neutralizing antibodies, COE (499-638 aa), SS2 (748-755 aa), SS6 (764-771 aa), and 2C10 (1368-1374 aa) [4]. The FJLY06 had 8 mutations compared to COE of the classical vaccine strain $\mathrm{CV} 777(\mathrm{I} \rightarrow \mathrm{H}$ at $521, \mathrm{~S} \rightarrow$ $\mathrm{G}$ at $523, \mathrm{~V} \rightarrow \mathrm{I}$ at $527, \mathrm{~T} \rightarrow \mathrm{S}$ at $550, \mathrm{G} \rightarrow \mathrm{S}$ at 594 , $\mathrm{A} \rightarrow \mathrm{E}$ at $605, \mathrm{~L} \rightarrow \mathrm{F}$ at 612 , and $\mathrm{I} \rightarrow \mathrm{V}$ at 635 ). In the other three neutralizing epitopes compared with CV777, there was only one mutation in the other three neutralizing epitopes $(\mathrm{Y} \rightarrow \mathrm{S}$ at 766 , in SS6), suggesting that CV777-based vaccines are not effective to prevent and control PEDV epidemics, indicating the need to develop and select new vaccines.

Nucleotide sequence similarity were assessed by SimPlotv.3.5.1, and showed that the FJLY06 is very similar to other sequences in G2 group (Fig. 1d) and can be inferred from the same ancestor. However, there were differences between Fujian's strains and reference strains in G1 group (Fig. 1d), located within $\mathrm{N}$-terminus of the $\mathrm{S}$ protein (Fig. 2), suggested this region in the $\mathrm{S}$ gene exhibited an increased divergence compared to the remaining part of the sequence, and the recently isolated

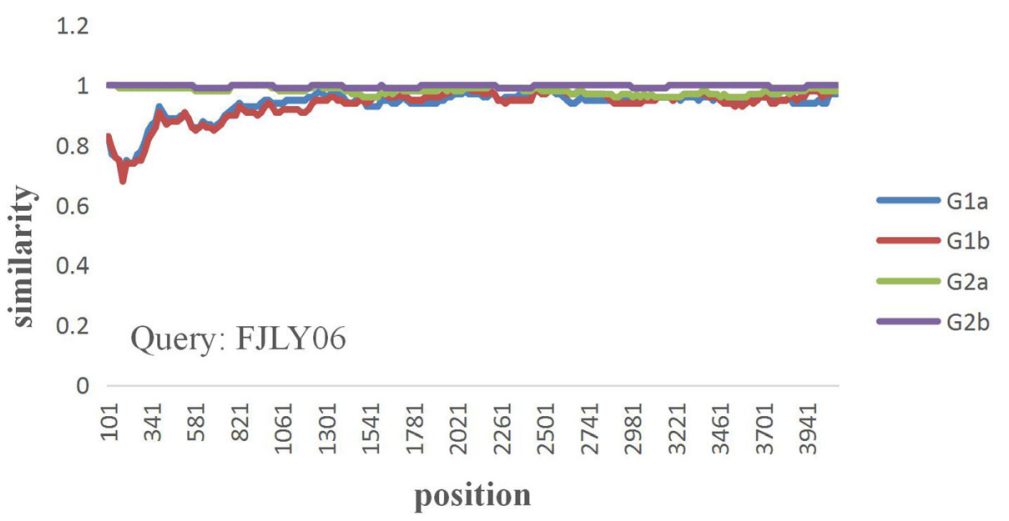

Fig. 2 Detection of potential recombination events in FJLY06. SimPlot analysis for possible recombination events of S genes of Fujian's strains compared to the G1 and G2 groups 
prevailing PEDV strain in Fujian is a novel strains with a variant $\mathrm{S}$ gene and maybe originated between classical and variant strains $[5,6]$.

\section{Abbreviations}

PEDV: Porcine epidemic diarrhea virus

\section{Acknowledgements}

No applicable.

\section{Authors' contributions}

Bo Dong and Xiaoyan Yang conceived and designed the experiments, participated in the sequence alignment and drafted the manuscript. Xiaohua $\mathrm{Li}$ analyzed the data. Ailing Dai participated in the design of the study and performed the statistical analysis. All authors read and approved the final manuscript.

\section{Funding}

This study was supported by Major projects of Key project of Fujian provincial youth natural fund (JZ160481) and Education and scientific research projects of young and middle-aged teachers in Fujian Province (JAT160483).

\section{Availability of data and materials}

The data analyzed during the current study was available from the corresponding author on reasonable request.

\section{Ethics approval and consent to participate}

This study based on samples collected intestinal contents of pigs that died spontaneously and were submitted for routine diagnonsis by the owners. Informed consent was obtained from all individual participants included in the study.

\section{Consent for publication}

No applicable.

\section{Competing interests}

The authors declare that they have no conflict of interest.

\section{Author details}

${ }^{1}$ College of Life Science of Longyan University, Longyan 364012, China

${ }^{2}$ Fujian Provincial Key Laboratory for the Prevention and Control of Animal

Infectious Diseases and Biotechnology, Longyan 364012, China.

Received: 23 April 2020 Accepted: 2 June 2020

Published online: 18 June 2020

\section{References}

1. Pensaert MB, De Bouck P. A new coronavirus-like particle associated with diarrhea in swine. Arch Virol. 1978;58(3):243-7.

2. Li R, Qiao S, Yang Y, et al. Genome sequencing and analysis of a novel recombinant porcine epidemic diarrhea virus strain from Henan, China. Virus Genes. 2016:52(1):91-8.

3. Li W, Li H, LiU Y, et al. New variants of porcine epidemic diarrhea virus, China, 2011. Emerg Infect Dis. 2012;18(8):1350.

4. Zhao J, Shi B, Huang X, et al. A multiplex RT-PCR assay for rapid and differential diagnosis of four porcine diarrhea associated viruses in field samples from pig farms in East China from 2010 to 2012. J Virol Methods. 2013:194(1-2):107-12.

5. Guo J, Fang L, Ye X, et al. Evolutionary and genotypic analyses of global porcine epidemic diarrhea virus strains. Transbound Emerg Dis. 2019;66(1): $111-8$.

6. Wang D, Fang L, Xiao S. Porcine epidemic diarrhea in China. Virus Res. 2016; 226:7-13.

\section{Publisher's Note}

Springer Nature remains neutral with regard to jurisdictional claims in published maps and institutional affiliations.

Ready to submit your research? Choose BMC and benefit from:

- fast, convenient online submission

- thorough peer review by experienced researchers in your field

- rapid publication on acceptance

- support for research data, including large and complex data types

- gold Open Access which fosters wider collaboration and increased citations

- maximum visibility for your research: over $100 \mathrm{M}$ website views per year

At $\mathrm{BMC}$, research is always in progress.

Learn more biomedcentral.com/submissions 